\title{
An empirical study on the key success factors of ppp-based PCA in the big data environment -- a case study of China
}

\author{
Bowen $\mathrm{Su}^{1, \mathrm{a}}$, Qiliang $\mathrm{Hu}^{2, \mathrm{~b}}$ \\ ${ }^{1}$ Commercial Circulation College, Anhui Institute of International Business, Hefei,231131, China \\ ${ }^{2}$ School of management, Anhui Business Vocational College, Hefei, 231131, China
}

\begin{abstract}
Public-private partnerships (PPPS) are increasingly being used in the construction of public services such as infrastructure in China. In the process of PPP project implementation, there are successes and failures, and the key factors of success are not completely clear. In order to identify the key factors for the success of PPP projects in the big data environment, PCA analysis is used to solve the problem of how to identify the key factors for the success of PPP projects in the big data environment. By studying the big data of PPP project and relevant literature at home and abroad, 32 potential key factors for success were constructed. The key success factors of PPP project were analyzed by questionnaire survey and principal component analysis. The results show that the 32 key factors for success can be summarized into five categories: political and economic environment, project development and operation management, government support and participation, government credit and commitment, strength of stakeholders, and factors of project bidding and procurement. Among the five factors, the key factors for the success of PPP projects are the continuous optimization of PPP policies, the rational project risk sharing mechanism, the guarantee and commitment of the government, the integrity and stability of government personnel, the satisfaction of public interests, and the complete financial analysis. This PCA method effectively solves the key factors for the success of PPP projects in the big data environment, ensures the smooth implementation of PPP projects, and promotes the long-term development of PPP projects.
\end{abstract}

\section{Introdution}

\subsection{Research on PPP projects in big data environment}

Public-private partnership project (PPP) is a cooperative mode between the government and social capital. The government uses the financial advantages of social capital for infrastructure construction. In the implementation process, the use of big data will get twice the result with half the effort. Guo (2019) used big data to supervise PPP projects and ensure the smooth implementation of projects. Wang(2019) audited PPP projects with the help of big data, and monitored the implementation of PPP projects in real time; Nie (2018) combed through the big data of PPP projects, and it was easy to find problems in PPP projects and improve them.

\subsection{Study on key factors for the success of PPP projects}

There is a lot of research on the key factors for the success of PPP project by domestic and foreign experts and scholars. Tiong (1992) believes that "the feasibility and necessity of the project" is the key to the success through BOT project research. Zhang (2010) concluded from 7 dimensions of performance impact and 4 dimensions of performance evaluation of domestic and foreign PPP projects that the key to success is reasonable project pricing and rich project management experience. $\mathrm{Ng}$ (2012) studied government departments and social capital parties related to PPP, and concluded that the three factors for success were the efficient construction capacity of the project team, the reasonable capital structure of the partners and the stable macro policy environment. Khalid (2017) reviewed the literature to extract 11 key factors for success, and concluded by regression analysis that project risk sharing mechanism and reward and punishment mechanism were the key factors for success. Chou (2015) concluded from the analysis of 15 driving factors that stable market demand and revenue, project negotiation cost and efficient private sector financing are the keys to success. Aerts (2014) analyzed 21 PPP projects and concluded that "correct financial evaluation" was the key factor. Wang (2007) studied domestic and foreign PPP projects and concluded that it is the key to success for the government to correctly perform its functions and make the team professional and efficient in communication. Zhang (2018) concluded from the case study of the success and

a63665222@qq.com; bhuqiliang123@126.com 
failure of the PPP project that the supervision mechanism system in the contract and the strength of the public subject were the key factors for the success. Mladenovic (2013) used KPI indicators to calculate that social and economic benefits, social public support and income are the key to success; Babatunde (2012) concluded from the study on the whole cycle of PPP projects that fairness in bidding and procurement procedures, government commitment and government political stability were the key success factors. Li (2018) concluded from the research on PPP construction in the process of urbanization that the technical plan is reasonable and the sound legal framework is the key to success. Among the key factors for the success of PPP project, Grimsey (2010) believes that government compensation mechanism and approval process are one of the keys to success. Bing (2005) studied 18 key success factors of British PPP project and concluded that private consortium, risk allocation and financial market are the keys to success. Osei-kyei (2015) summarized that the success factors of PPP projects are sound economic policies and good reputation of the public sector through the review of literatures from 1990 to 2013. According to Zhao (2016), based on the characteristics of infrastructure construction, through regression analysis, it is concluded that stable macro environment, superior natural environment and ppp-related policies are the success factors of PPP projects.

\subsection{PPP project research based on PCA}

$\mathrm{Lu}$ (2017) studied the risks of basic implementation through PCA method, and conducted empirical study on 10 PPP projects in Zhejiang province, and concluded that the forecast was consistent with the actual risks. Zhang (2016) studied the risks of low-rent housing PPP projects with PCA and predicted the risks. Huang (2019) constructed a $3 \mathrm{~d}$ structural model for risks generated in the whole life cycle of PPP projects and dynamically analyzed risks in each stage.

\section{Methods}

\subsection{Participants}

With the help of the big data of PPP project, this study sent questionnaires to the groups of government, social capital parties and consulting companies that participated in the PPP project. It lasted for 2 months and 120 questionnaires were recovered. Among them, 1 was rejected due to the inconsistencies and other unqualified questionnaires. In the sample, the average working years of the respondents reached 8.2 years, and they all participated in a number of PPP projects, involving 19 industries, with a total of 168 participants. In all industries, 30 person-times for municipal projects (17.86\%), 22 person-times for transportation (13.10\%), 15 person-times for ecological construction and environmental protection $(8.93 \%), 15$ person-times for government infrastructure $(8.93 \%), 12$ person-times for education $(7.14 \%), 12$ person-times for comprehensive urban development (7.14\%), 10 person-times for water conservancy projects $(5.95 \%), 6$ person-times for government-subsidized housing (3.57\%), 5 person-times for social security (2.98\%), 4 person-times for old-age care $(2.38 \%), 3$ person-times for science and technology $(1.79 \%), 2$ person-times for energy $(1.19 \%)$, and 2 person-times for sports $(1.19 \%), 2$ person-times in agriculture $(1.19 \%), 2$ person-times in other fields $(1.19 \%)$, and 1 person-times in forestry $(0.60 \%)$. Therefore, it can be seen that respondents have rich experience in PPP projects to ensure the reliability of the data.

\subsection{Measures}

1) Establishment of key success factors system for PPP projects: Based on theoretical research and literature review, the construction of index system for the critical success factor of the PPP projects, a total set to 32 indicators, each indicator to score in the form of questionnaire in the form of likert scale to "is not the key", "key", "general", "critical", "critical" press 1, 2, 3, 4, 5 points, the concrete index system are shown in table 1.

2) Construct the principal component analysis model of PPP project: Principal component analysis (PCA) is to recombine a series of correlated data into data with no correlation through dimensionality reduction, and replace the original data with these data to reflect the original indicators. Through the reduction of dimension by SPSS software, it is concluded that the side difference of linear combination is the largest, which means that F1 contains more information, so F1 is called the first principal component. If the first principal component cannot reflect the information of all the original indexes, the second principal component needs to be selected to continue to reflect the original data information. Then the second principal component is represented by F2. In order to ensure that the original information is not missing, if the original data information cannot be fully reflected, then extract the third, fourth,..., The $\mathrm{P}$ th principal component.

TABLE I.Key SuCCESS Factors ofPPP Projects

\begin{tabular}{|c|c|c|c|c|}
\hline Indicators of key success factors & variable & Indicators of key success factors & variable \\
\hline The project pricing mechanism is reasonable & $\mathrm{X}_{1}$ & The public interest is fully satisfied & $\mathrm{X}_{17}$ \\
\hline $\begin{array}{c}\text { The ability of the project team to build } \\
\text { efficiently }\end{array}$ & $\mathrm{X}_{2}$ & The private sector is strong & $\mathrm{X}_{18}$ \\
\hline
\end{tabular}




\begin{tabular}{|c|c|c|c|}
\hline The project is feasible and necessary & $\mathrm{X}_{3}$ & The government is clean and stable & $\mathrm{X}_{19}$ \\
\hline $\begin{array}{c}\text { Rich experience in project development and } \\
\text { management }\end{array}$ & $\mathrm{X} 4$ & Full financial analysis & $\mathrm{X}_{20}$ \\
\hline $\begin{array}{c}\text { The project risk sharing mechanism is } \\
\text { reasonable }\end{array}$ & $\mathrm{X}_{5}$ & $\begin{array}{l}\text { The technical plan is reasonable and } \\
\text { effective }\end{array}$ & $\mathrm{X}_{21}$ \\
\hline $\begin{array}{l}\text { The project reward and punishment mechanism } \\
\text { is reasonable }\end{array}$ & $\mathrm{X}_{6}$ & $\begin{array}{c}\text { Efficient communication and } \\
\text { coordination between government } \\
\text { departments }\end{array}$ & $\mathrm{X}_{22}$ \\
\hline $\begin{array}{l}\text { The private sector has efficient and innovative } \\
\text { financing methods }\end{array}$ & $\mathrm{X}_{7}$ & $\begin{array}{c}\text { The government approval process is } \\
\text { efficient }\end{array}$ & $\mathrm{X}_{23}$ \\
\hline Fair competition in recruitment procedures & $\mathrm{X}_{8}$ & Effective regulatory regime & $X_{24}$ \\
\hline $\begin{array}{c}\text { The government team is professional and } \\
\text { efficient }\end{array}$ & $\mathrm{X}_{9}$ & Financial markets are stable and available & $\mathrm{X}_{25}$ \\
\hline $\begin{array}{l}\text { The government compensation mechanism is } \\
\text { reasonable }\end{array}$ & $\mathrm{X}_{10}$ & Sound economic policy & $\mathrm{X}_{26}$ \\
\hline $\begin{array}{c}\text { The social and economic benefits of the project } \\
\text { are significant }\end{array}$ & $\mathrm{X}_{11}$ & Sound legal framework & $\mathrm{X}_{27}$ \\
\hline Partner capital structure is reasonable & $\mathrm{X}_{12}$ & $\begin{array}{c}\text { The public sector is well organised and } \\
\text { reputable }\end{array}$ & $\mathrm{X}_{28}$ \\
\hline $\begin{array}{l}\text { Government guarantees and commitments are } \\
\text { valid }\end{array}$ & $\mathrm{X}_{13}$ & Superior natural environment & $\mathrm{X}_{29}$ \\
\hline The recruitment process is open and transparent & $\mathrm{X}_{14}$ & $\begin{array}{c}\text { Strong market demand and stable } \\
\text { earnings }\end{array}$ & $\mathrm{X}_{30}$ \\
\hline Project negotiation costs are relatively low & $\mathrm{X}_{15}$ & $\begin{array}{l}\text { The PPP project policy has been } \\
\text { continuously optimized and improved }\end{array}$ & $\mathrm{X}_{31}$ \\
\hline The public fully supports the project & $\mathrm{X}_{16}$ & Macroscopic environmental stability & $\mathrm{X}_{32}$ \\
\hline
\end{tabular}

First, the software SPSS24.0 was used to reduce the dimension of the data, and then the linear equation of the principal component was obtained, as follows:

$$
\begin{aligned}
& \mathrm{F}_{1}=\mathrm{a}_{11} \mathrm{X}_{1}+\mathrm{a}_{21} \mathrm{X}_{2} \ldots \ldots+\mathrm{a}_{\mathrm{p} 1} \mathrm{X}_{\mathrm{p}}(1) \\
& \mathrm{F}_{2}=\mathrm{a}_{12} \mathrm{X}_{1}+\mathrm{a}_{22} \mathrm{X}_{2} \ldots \ldots+\mathrm{a}_{\mathrm{p} 2} \mathrm{X}_{\mathrm{p}}(2) \\
& \ldots \\
& \quad \mathrm{F}_{\mathrm{p}}=\mathrm{a}_{1 \mathrm{~m}} \mathrm{X}_{1}+\mathrm{a}_{2 \mathrm{~m}} \mathrm{X}_{2}+\ldots \ldots+\mathrm{a}_{\mathrm{pm}} \mathrm{X}_{\mathrm{p}}(3)
\end{aligned}
$$

Among them, $a_{1 i}, a_{2}, \ldots, a_{p i}(i=1, \ldots, m)$ is the eigenvector corresponding to the eigenvalue of the covariance matrix of $\mathrm{X}, \mathrm{X} 1, \mathrm{X} 2, \ldots, \mathrm{Xp}$ is the original variable.

Secondly, the proportion of the corresponding eigenvalues of each principal component to the sum of the total eigenvalues of the extracted principal component is used as the weight to calculate the principal component synthesis model:

$$
\mathrm{F}=\frac{\lambda_{1}}{\lambda_{1}+\lambda_{2}+\cdots \lambda_{p}} F_{1}+\frac{\lambda_{2}}{\lambda_{1}+\lambda_{2}+\cdots \lambda_{p}} F_{2}+\cdots+\frac{\lambda_{n}}{\lambda_{1}+\lambda_{2}+\cdots \lambda_{p}} F_{n}(4)
$$

\section{Results}

\subsection{Analysis procedure}

Cronbach's Alpha was used for reliability analysis, and the Cronbach's score was 0.980, greater than 0.9, indicating a very good reliability. The combined reliability $C R$ value was 0.9158 , which exceeded the critical value of 0.7 , indicating that the combined reliability was very good. The AVE value of the average extraction variance is 0.6895 , which exceeds the critical value of 0.5 , indicating a good convergence validity. Combined, the data are very reliable. KMO and bartlett test showed that the KMO value was 0.941, the approximate chi-square value was 4084.056 , and the sig value of significance test was 0.000 , indicating that the validity of the questionnaire was very high and it was suitable for factor analysis.

\subsection{Data analysis}

1)Common factor variance: The variance extraction values of the common factor are all above 1 , and only 6 variables are above 0.8 , all of which are above 0.7 , indicating that the extracted variables carry the original information and the extracted principal component variables are closely related to each other, indicating that the principal component analysis can be further carried out, as shown in table2. 
TABle II.COMmon Factor Variance of Key Success VARiables

\begin{tabular}{|c|c|c|c|c|c|c|c|c|}
\hline Variable & Initial & Extraction & Variable & Initial & Extraction & Variable & Initial & Extraction \\
\hline $\mathrm{X}_{1}$ & 1.356 & 1.095 & $\mathrm{X}_{12}$ & 1.436 & 1.112 & $\mathrm{X}_{23}$ & 1.038 & 0.848 \\
\hline $\mathrm{X}_{2}$ & 1.661 & 1.345 & $\mathrm{X}_{13}$ & 1.494 & 1.233 & $\mathrm{X}_{24}$ & 1.415 & 1.200 \\
\hline $\mathrm{X}_{3}$ & 1.422 & 1.200 & $\mathrm{X}_{14}$ & 1.460 & 1.109 & $\mathrm{X}_{25}$ & 1.559 & 1.341 \\
\hline $\mathrm{X}_{4}$ & 1.576 & 1.255 & $\mathrm{X}_{15}$ & 1.213 & 0.802 & $\mathrm{X}_{26}$ & 1.236 & 0.963 \\
\hline $\mathrm{X}_{5}$ & 1.300 & 1.016 & $\mathrm{X}_{16}$ & 1.488 & 1.198 & $\mathrm{X}_{27}$ & 1.506 & 1.225 \\
\hline $\mathrm{X}_{6}$ & 1.151 & 0.902 & $\mathrm{X}_{17}$ & 1.415 & 1.060 & $\mathrm{X}_{28}$ & 1.194 & 0.937 \\
\hline $\mathrm{X}_{7}$ & 1.491 & 1.208 & $\mathrm{X}_{18}$ & 1.446 & 1.204 & $\mathrm{X}_{29}$ & 1.094 & 0.800 \\
\hline $\mathrm{X}_{8}$ & 1.495 & 1.317 & $\mathrm{X}_{19}$ & 1.256 & 0.959 & $\mathrm{X}_{30}$ & 1.042 & 0.842 \\
\hline $\mathrm{X}_{9}$ & 1.338 & 1.004 & $\mathrm{X}_{20}$ & 1.433 & 1.113 & $\mathrm{X}_{31}$ & 1.364 & 1.080 \\
\hline $\mathrm{X}_{10}$ & 1.317 & 1.098 & $\mathrm{X}_{21}$ & 1.114 & 0.873 & $\mathrm{X}_{32}$ & 1.286 & 1.018 \\
\hline $\mathrm{X}_{11}$ & 1.610 & 1.183 & $\mathrm{X}_{22}$ & 1.075 & 0.776 & & & \\
\hline
\end{tabular}

2)Principal component analysis of key success factors: The principal component analysis of key success factors is as follows.

a) Determine the principal component, characteristic value and contribution rate of key success factors: Among the 32 variables that are the key factors for the success of PPP project, SPSS24.0 software is used to conduct dimensionality reduction processing on the data, extract 6 components whose characteristic value is greater than 1 , and obtain the cumulative contribution rate. The cumulative contribution rate reached $81.134 \%$, and the contribution rate was greater than $80 \%$, with a high reliability, indicating that these six components can reflect the information of the data. Therefore, the first six components as the main components can evaluate the risk of the whole cycle, as shown in table 3 . The four principal components were F1, F2, F3, F4, F5 and F6, and their characteristic values were $26.687,2.330,1.829,1.672,1.388$ and 1.209, respectively. The contribution rate was $61.661 \%$, $67.044 \%, 71.270 \%, 75.134 \%$, and $78.341 \%$, respectively, and the total contribution rate reached $81.134 \%$. Principal component analysis can be conducted, as shown in table 4.

TABLE III. TOTAL VARIANCE EXPLAINED

\begin{tabular}{|c|c|c|c|c|c|c|}
\hline \multirow{2}{*}{ Component } & \multicolumn{3}{|c|}{ Initial Eigenvalues } & \multicolumn{3}{c|}{ Extract the sums of squared loadings } \\
\cline { 2 - 7 } & Total & $\begin{array}{c}\text { \% of } \\
\text { Variance }\end{array}$ & Cumulative \% & Total & \% of Variance & Cumulative \% \\
\hline 1 & 26.687 & 61.661 & 61.661 & 26.687 & 61.661 & 61.661 \\
\hline 2 & 2.330 & 5.383 & 67.044 & 2.330 & 5.383 & 67.044 \\
\hline 3 & 1.829 & 4.226 & 71.270 & 1.829 & 4.226 & 71.270 \\
\hline 4 & 1.672 & 3.864 & 75.134 & 1.672 & 3.864 & 75.134 \\
\hline 5 & 1.388 & 3.207 & 78.341 & 1.388 & 3.207 & 78.341 \\
\hline 6 & 1.209 & 2.793 & 81.134 & 1.209 & 2.793 & 81.134 \\
\hline 7 & 0.628 & 1.451 & 82.585 & & & \\
\hline 8 & 0.602 & 1.390 & 82.585 & & & \\
\hline$\ldots$ & $\ldots$ & $\ldots$ & $\ldots$ & & & \\
\hline 31 & 0.078 & 0.181 & 99.855 & & & \\
\hline 32 & 0.063 & 0.145 & 100.000 & & & \\
\hline
\end{tabular}

Table 4. Extract Principal Component and Feature Value Table

\begin{tabular}{|c|c|c|c|c|c|c|c|}
\hline Component & $\boldsymbol{F 1}$ & $\boldsymbol{F 2}$ & $\boldsymbol{F 3}$ & $\boldsymbol{F 4}$ & $\boldsymbol{F 5}$ & $\boldsymbol{F 6}$ & Cumulative \\
\hline Eigenvalues $\lambda$ & 26.687 & 2.33 & 1.829 & 1.672 & 1.388 & 1.209 & \\
\hline Cumulative $\%$ & 61.661 & 5.383 & 4.226 & 3.864 & 3.207 & 2.793 & 81.134 \\
\hline
\end{tabular}

b) Classification of key success factors: After factor analysis, the key success factors of 32 PPP projects were divided into 6 categories, namely, 6 principal components. The component matrix after 7 bits rotation was shown in table. For the sake of data simplicity, the value below 0.4 was removed. The variables in the first category are $\mathrm{X}_{25}, \mathrm{X}_{31}, \mathrm{X}_{27}, \mathrm{X}_{24}, \mathrm{X}_{26}, \mathrm{X}_{32}, \mathrm{X}_{28}, \mathrm{X}_{30}$, and $X_{29}$. It is found that such indicators can be divided into political and economic environments. By analogy, the second category is divided into project development and operation management, the third category is divided into 
government support and participation, the fourth category is divided into government credit and commitment, the fifth category is divided into the strength of stakeholders, and the sixth category is divided into project recruitment factors, as shown in table 5 .

TABle 5. Success Critical Factor Rotation COMPONENT MatriX

\begin{tabular}{|c|c|c|c|c|c|c|c|c|c|c|c|c|c|}
\hline \multirow{2}{*}{ Variable } & \multicolumn{6}{|c|}{ Component } & \multirow{2}{*}{ Variable } & \multicolumn{6}{|c|}{ Component } \\
\hline & 1 & 2 & 3 & 4 & 5 & 6 & & 1 & 2 & 3 & 4 & 5 & 6 \\
\hline $\mathrm{X}_{25}$ & 1.054 & & & & & & $X_{6}$ & & 0.583 & & & & 0.511 \\
\hline$X_{31}$ & 0.856 & & & & & & $X_{15}$ & & 0.585 & & & & \\
\hline$X_{27}$ & 0.898 & & & & & & $\mathrm{X}_{10}$ & & & 0.894 & & & \\
\hline $\mathrm{X}_{24}$ & 0.870 & & & & & & $X_{13}$ & & & 0.893 & & & \\
\hline $\mathrm{X}_{26}$ & 0.799 & & & & & & $\mathrm{X}_{9}$ & & & 0.712 & & & \\
\hline $\mathrm{X}_{32}$ & 0.775 & & & & & & $\mathrm{X}_{19}$ & & & 0.679 & & & \\
\hline $\mathrm{X}_{28}$ & 0.728 & & & & & & $X_{23}$ & & & & 0.718 & & \\
\hline $\mathrm{X}_{30}$ & 0.657 & & & & & & $\mathrm{X}_{22}$ & 0.454 & & & 0.562 & & \\
\hline $\mathrm{X}_{29}$ & 0.628 & & & & & & $X_{17}$ & & & & & & \\
\hline $\mathrm{X}_{2}$ & & 1.019 & & & & & $\mathrm{X}_{16}$ & & 0.510 & & & 0.744 & \\
\hline$X_{3}$ & & 0.937 & & & & & $\mathrm{X}_{18}$ & & & & 0.624 & 0.703 & \\
\hline $\mathrm{X}_{4}$ & & 0.947 & & & & & $\mathrm{X}_{12}$ & & 0.515 & 0.486 & & 0.641 & \\
\hline $\mathrm{X}_{11}$ & & 0.835 & & & & & $\mathrm{X}_{14}$ & & 0.547 & & & 0.643 & \\
\hline $\mathrm{X}_{7}$ & & 0.774 & & & & 0.500 & $\mathrm{X}_{8}$ & & & & & 0.573 & 0.738 \\
\hline $\mathrm{X}_{5}$ & & 0.683 & & & & & $X_{21}$ & 0.481 & & & & & 0.539 \\
\hline $\mathrm{X}_{1}$ & & 0.685 & & 0.681 & & & $\mathrm{X}_{20}$ & 0.577 & & & & & 0.609 \\
\hline
\end{tabular}

c) weight analysis of key factors of success: Through the principal component load matrix analysis, see the "principal component load number" in table 7, the principal component load number can reflect the information of the index. The combination coefficient of principal components is calculated by dividing the load number of the corresponding risk index by the square root of the characteristic value of principal components, as shown in table 7, "combination coefficient of principal components", and the mathematical model of principal components is established according to the combination coefficient.

$\mathrm{F} 1=0.184 \mathrm{X}_{25}+0.182 \mathrm{X}_{31}+0.189 \mathrm{X}_{27} \ldots+0.187 \mathrm{X}_{8}+0.163$ $\mathrm{X}_{21}+0.178 \mathrm{X}_{20}$

$\mathrm{F} 2=0.372 \mathrm{X}_{25}+0.263 \mathrm{X}_{31}+0.245 \mathrm{X}_{27} \ldots-0.162 \mathrm{X}_{8}+0.091$ $\mathrm{X}_{21}-0.116 \mathrm{X}_{20}$

$\mathrm{F} 3=-0.108 \mathrm{X}_{25}-0.005 \mathrm{X}_{31}-0.028 \mathrm{X}_{27} \ldots+0.080 \mathrm{X}_{8}+0.026$ $\mathrm{X}_{21}-0.049 \mathrm{X}_{20}$

$\mathrm{F} 4=-0.156 \mathrm{X}_{25}+0.064 \mathrm{X}_{31}-0.239 \mathrm{X}_{27} \ldots+0.028 \mathrm{X}_{8}+0.264$ $\mathrm{X}_{21}+0.353 \mathrm{X}_{20}$
$\mathrm{F} 5=-0.197 \mathrm{X}_{25}-0.071 \mathrm{X}_{31}-0.122 \mathrm{X}_{27} \ldots+0.013 \mathrm{X}_{8}+0.057$

$\mathrm{X}_{21}-0.016 \mathrm{X}_{20}$

$\mathrm{F} 6=-0.004 \mathrm{X}_{25}+0.041 \mathrm{X}_{31}+0.107 \mathrm{X}_{27} \ldots-0.502 \mathrm{X}_{8}-0.137$ $\mathrm{X}_{21}-0.149 \mathrm{X}_{20}$

Through the principal component mathematical model, the comprehensive score of each key factor of success was calculated.

$\mathrm{F}=\frac{v_{1}}{v_{1}+v_{2}+\cdots v_{n}} F_{1}+\frac{v_{2}}{v_{1}+v_{2}+\cdots v_{n}} F_{2}+\cdots+\frac{v_{n}}{v_{1}+v_{2}+\cdots v_{n}} F_{n}(5)$

$v_{n}(\mathrm{n}=1,2,3 \ldots)$ represents the variance contribution rate of extracted principal components. In this model, 6 principal components are extracted, that is, $n=6$. The key factors of success were calculated and the comprehensive scores of each index were obtained. "X25", for example, the comprehensive score $=61.661$ / $81.134 * 0.187+5.383 / \quad 81.134 * 0.372+\quad 4.226 /$ $81.134 *(-0.108)+3.865 /$

$81.134 *(-0.156)+3.207 / 81.134 *(-0.197)+2.793 /$

$81.134 *(-0.004)=0.151$. By analogy, the comprehensive score of all the key factors of success is obtained.

By normalizing the weight of the comprehensive scores of all key success factors, the weight of each is obtained, as shown in table 6 .

Table 6. Principal Component Load, Combination Coefficient, Composite Score and Weight Table

\begin{tabular}{|c|c|c|c|c|c|c|c|c|c|c|c|c|c|c|}
\hline \multirow{2}{*}{$\begin{array}{l}\text { Vari } \\
\text { able }\end{array}$} & \multicolumn{6}{|c|}{ Principal component loadings } & \multicolumn{6}{|c|}{ Principal component combination coefficient } & \multirow{2}{*}{$\begin{array}{c}\text { Comp } \\
\text { osite } \\
\text { scores }\end{array}$} & \multirow{2}{*}{$\begin{array}{l}\text { Factor } \\
\text { weight }\end{array}$} \\
\hline & $F 1$ & $F 2$ & $F 3$ & F4 & $F 5$ & F6 & $F 1$ & $F 2$ & F3 & F4 & $F 5$ & F6 & & \\
\hline $\mathrm{X}_{25}$ & 0.950 & 0.568 & -0.146 & -0.201 & -0.232 & -0.005 & 0.184 & 0.372 & -0.108 & -0.156 & -0.197 & -0.004 & 0.151 & 0.035 \\
\hline
\end{tabular}




\begin{tabular}{|c|c|c|c|c|c|c|c|c|c|c|c|c|c|c|}
\hline$X_{31}$ & 0.940 & 0.401 & -0.141 & 0.083 & -0.083 & 0.045 & 0.182 & 0.263 & -0.105 & 0.064 & -0.071 & 0.041 & 0.153 & 0.036 \\
\hline$X_{27}$ & 0.977 & 0.374 & -0.038 & -0.309 & -0.143 & 0.118 & 0.189 & 0.245 & -0.028 & -0.239 & -0.122 & 0.107 & 0.147 & 0.034 \\
\hline$X_{24}$ & 905 & 0.434 & .204 & -0.294 & 0.119 & -0.226 & 0.175 & 0.284 & 0.151 & -0.227 & 0.101 & -0.206 & 0.132 & 0.031 \\
\hline $\mathrm{X}_{26}$ & 0.887 & 0.321 & -0.061 & -0.064 & -0.223 & 0.123 & 0.172 & 0.210 & -0.045 & -0.049 & -0.190 & 0.112 & 0.140 & 0.032 \\
\hline$X_{32}$ & 873 & 0.362 & .161 & .258 & 0.050 & 0.171 & 0.169 & 0.237 & 0.119 & 0.199 & -0.042 & 0.156 & 0.148 & 0.034 \\
\hline $\mathrm{X}_{28}$ & 0.905 & 0.315 & -0.069 & 0.109 & 0.025 & 0.039 & 0.175 & 0.206 & -0.051 & 0.085 & 0.021 & 0.036 & 0.148 & 0.034 \\
\hline $\mathrm{X}_{30}$ & 0.872 & 0.249 & -0.003 & -0.108 & 0.088 & 0.002 & 0.169 & 0.163 & -0.002 & -0.083 & 0.075 & 0.002 & 0.135 & 0.031 \\
\hline $\mathrm{X}_{29}$ & 0.855 & 0.218 & -0.043 & -0.073 & 0.114 & 0.050 & 0.165 & 0.143 & -0.032 & -0.056 & 0.096 & 0.046 & 0.131 & 0.030 \\
\hline$X_{2}$ & 0.972 & -0.502 & -0.344 & -0.020 & 0.093 & 0.147 & 0.188 & -0.329 & -0.254 & -0.016 & 0.079 & 0.134 & 0.108 & 0.025 \\
\hline $\mathrm{X}_{3}$ & 0.952 & -0.305 & -0.440 & -0.044 & -0.006 & 0.067 & 0.184 & -0.200 & -0.326 & -0.034 & -0.005 & 0.061 & 0.109 & 0.025 \\
\hline $\mathrm{X}_{4}$ & 0.967 & -0.361 & -0.286 & 0.203 & -0.170 & 0.193 & 0.187 & -0.237 & -0.212 & 0.157 & -0.145 & 0.176 & 0.124 & 0.029 \\
\hline$X_{11}$ & 1.011 & .249 & -0.237 & -0.105 & -0.132 & 0.118 & 0.196 & -0.163 & -0.175 & -0.081 & -0.112 & 0.107 & 0.125 & 0.029 \\
\hline$X_{7}$ & 0.993 & -0.185 & -0.355 & 0.018 & -0.003 & -0.249 & 0.192 & -0.121 & -0.262 & 0.014 & -0.002 & -0.227 & 0.124 & 0.029 \\
\hline $\mathrm{X}_{5}$ & 951 & -0.178 & & 0.171 & 0.137 & -0.062 & 0.184 & -0.117 & -0.126 & 0.132 & 0.116 & -0.056 & 0.132 & 0.031 \\
\hline $\mathrm{X}_{1}$ & 0.875 & -0.200 & -0.113 & -0.020 & 0.373 & 0.371 & 0.169 & -0.131 & -0.083 & -0.016 & 0.317 & 0.338 & 0.117 & 0.027 \\
\hline $\mathrm{X}_{6}$ & 0.887 & -0.141 & -0.117 & 0.220 & 0.061 & -0.170 & 0.172 & -0.092 & -0.086 & 0.170 & 0.052 & -0.154 & 0.127 & 0.030 \\
\hline $\mathrm{X}_{15}$ & 0.870 & -0.186 & -0.023 & 0.021 & -0.099 & 0.012 & 0.168 & -0.122 & -0.017 & 0.017 & -0.084 & 0.011 & 0.120 & 0.028 \\
\hline$X_{10}$ & 841 & .067 & 0.490 & 250 & 0.288 & 0.013 & 0.163 & -0.044 & 0.362 & 0.193 & -0.245 & 0.012 & 0.149 & 0.034 \\
\hline$X_{13}$ & 0.934 & -0.099 & 0.476 & 0.123 & -0.183 & 0.276 & 0.181 & -0.065 & 0.352 & 0.095 & -0.155 & 0.251 & 0.157 & 0.036 \\
\hline $\mathrm{X}_{9}$ & 0.919 & -0.130 & 0.305 & 0.188 & -0.117 & 0.009 & 0.178 & -0.085 & 0.225 & 0.145 & -0.099 & 0.008 & 0.148 & 0.034 \\
\hline $\mathrm{X}_{19}$ & 0.857 & 0.030 & 0.445 & 0.147 & 0.054 & 0.027 & 0.166 & 0.020 & 0.329 & 0.114 & 0.046 & 0.024 & 0.150 & 0.035 \\
\hline$X_{23}$ & 0.750 & 0.081 & 0.229 & 0.058 & 0.394 & 0.260 & 0.145 & 0.053 & 0.170 & 0.045 & 0.334 & 0.237 & 0.127 & 0.029 \\
\hline $\mathrm{X}_{22}$ & 0.788 & 0.168 & 0.104 & 0.027 & 0.339 & -0.018 & 0.153 & 0.110 & 0.077 & 0.021 & 0.287 & -0.016 & 0.129 & 0.030 \\
\hline$X_{17}$ & 0.970 & 0.010 & 0.207 & -0.029 & 0.201 & -0.187 & 0.188 & 0.006 & 0.153 & -0.023 & 0.170 & -0.170 & 0.149 & 0.035 \\
\hline$X_{16}$ & 0.952 & -0.317 & 0.247 & -0.352 & -0.064 & -0.037 & 0.184 & -0.208 & 0.183 & -0.272 & -0.055 & -0.034 & 0.123 & 0.028 \\
\hline $\mathrm{X}_{18}$ & 0.918 & -0.070 & 0.306 & -0.365 & 0.346 & -0.099 & 0.178 & -0.046 & 0.226 & -0.282 & 0.294 & -0.090 & 0.130 & 0.030 \\
\hline$X_{12}$ & 0.936 & -0.218 & 0.192 & -0.345 & -0.140 & 0.115 & 0.181 & -0.143 & 0.142 & -0.267 & -0.119 & 0.104 & 0.123 & 0.029 \\
\hline $\mathrm{X}_{14}$ & 0.931 & -0.214 & 0.059 & -0.262 & -0.316 & -0.157 & 0.180 & -0.140 & 0.044 & -0.203 & -0.268 & -0.143 & 0.119 & 0.028 \\
\hline $\mathrm{X}_{8}$ & 0.969 & -0.248 & 0.108 & 0.036 & 0.015 & -0.552 & 0.187 & -0.162 & 0.080 & 0.028 & 0.013 & -0.502 & 0.134 & 0.031 \\
\hline $\mathrm{X}_{21}$ & 0.842 & 0.139 & 0.035 & 0.341 & 0.067 & -0.151 & 0.163 & 0.091 & 0.026 & 0.264 & 0.057 & -0.137 & 0.143 & 0.033 \\
\hline$X_{20}$ & 0.917 & 0.177 & -0.066 & 0.457 & -0.019 & -0.164 & 0.178 & 0.116 & -0.049 & 0.353 & -0.016 & -0.149 & 0.156 & 0.036 \\
\hline
\end{tabular}

optimization and improvement of PPP project policy has

\section{Discussion}

In the big data environment, there are 32 key success factors for PPP projects, which are classified according to the principal component and named the new category. According to the weight analysis of each principal component in table 7 , the following conclusions are drawn:

The first principal component of political and economic environment contains success factors are: financial market stability and enough available, the PPP project policy continuous optimization improvement, perfect legal framework, supervision mechanism, effective and stable economic policy, macro environment, public sector organizations and have good reputation, market demand and income stability, the natural environment is superior. In this principal component, the success factor of continuous the highest weight (0.036), indicating that the success factor is the most critical. The second is that financial markets are stable and sufficiently available (0.035), and the lowest weight is that the natural environment is superior $(0.003)$.

Project development and operation management of the second principal components include success factors are: the efficient construction of ability of the project team, project has the feasibility and necessity, rich experience in project development and management, and project of social and economic benefit is remarkable, the private sector, efficiency of the financing way of innovation, reasonable project risk sharing mechanism, project reasonable pricing mechanism, reasonable rewards and punishment mechanism, project negotiation cost is low. In this principal component, the success factor with reasonable project risk sharing mechanism has the highest weight $(0.031)$, followed by reasonable 
project reward and punishment mechanism (0.030), and the lowest weight is team building ability (0.250).

The third principal component of government support and participation mainly includes: the government compensation mechanism is reasonable, the government guarantee and commitment is effective, the government team is professional and efficient, weight is $0.034,0.036,0.034$, indicating that the government guarantee and commitment is the most important.

The fourth principal component of government credit mainly includes: clean and stable government personnel, efficient government approval process, efficient communication and coordination between government departments, with weights of $0.035,0.029$ and 0.030 respectively, indicating that clean and stable government personnel are the most important factors.

The fifth principal component of the strength of stakeholders mainly includes: the public interest is fully satisfied, the public fully supports the project, the private sector is strong, the partner capital structure is reasonable, the weight is $0.035,0.028,0.030,0.029$. The satisfaction of the public interest is the first key factor for success.

The sixth principal component of the project recruitment factors mainly include: the recruitment process open and transparent, the recruitment process fair competition, the technical program reasonable and effective, the financial analysis is fully complete, weight is $0.028,0.031,0.033,0.036$. It can be seen from the data that complete financial analysis is the first element of success.

\section{Conclusion}

This study aims to explore the key factors for the success of pca-based PPP projects in the big data environment. Considering that there are few comprehensive studies in the east, especially in mainland China, this fills the literature on the use of big data and PCA models to analyze the key factors for the success of PPP projects. The big data shows that the key factors for the success of PPP projects are the continuous optimization of PPP policies, the reasonable project risk sharing mechanism, the guarantee and commitment of the government, the integrity and stability of government personnel, the full satisfaction of the public interest, and the complete financial analysis. This study also discusses the methods of identifying different key success factors under different PPP project industry backgrounds. Finally, it is hoped that the results of this study can be provided to the policy discussion of the designers of PPP projects to meet the demand.

\section{Authors}

Bowen $\mathrm{Su}$, is an associate professor at Anhui International Business Vocational College in China, Her main areas of research interest are PPP project management.
Qiliang $\mathrm{Hu}$, is a lecturer at Anhui Business Vocational College in China, His main areas of research interest are enterprise management

\section{Acknowledgement}

Thanks for this research funded by the natural science key project fund of Anhui provincial department of education (grant no: KJ2019A1169). Thanks for this research funded by the foundation of quality engineering high-level vocational specialty construction project of Anhui provincial department of education (grant no: 2018ylzy136).

\section{References}

1. Guo,W.Z., \& 1,W.K. Research on purchasing methods of PPP projects from the perspective of big data supervision -- a case study of 67 PPP warehousing projects in Beijing $[\mathrm{J}]$. Financial supervision, 2019 (23) : 17-21.

2. Wang,A.H., \& Ma,X.H. Construction of big data audit model for PPP projects [J]. Journal of finance and economics, 2019 (03) : 116-124.

3. Tiong,R.L.K., Yeo.K.T., \& Mc,Carthy.S.C.Critical success factors in winning BOT contracts[J].Journal of Construction Engineering and Management, 1992, 118 (2) :217-228.

4. Zhang,W.K.,Yang,Y.S., \& Wang,Y.Q.Key influencing factors of public-private partnership performance -- a study based on the experience of several countries in transition [J]. Journal of public administration, 2010,7 (3) : 103-112.

5. Ng,S.T., Wong,Y.M.W., \& Wong,J.M.W.Factors influencing the success of PPP at feasibility stage-A tripartite comparison study in Hong Kong[J].Habitat International, 2012, 36 (4) :423-432.

6. Almarri.Khalid., \& Boussabaine.H. Interdependency of the critical success factors and ex-post performance indicators of PPP projects[J]. Built Environment Project and Asset Management,2017,7(5):546-556.

7. Chou.J.S., \& Pramudawardhani.D. Cross-country comparisons of key drivers, critical success factors and risk allocation for public-private partnership projects[J].International Journal of Project Management, 2015, 33 (5) :1136-1150.

8. Aerts,G., Grage.T., Dooms,M., et al. Public-Private Partnerships for the provision of port Infrastructure:an explorative multi-Actor perspective on critical success factors[J].The Asian Journal of Shipping and Logistics, 2014, 30 (3) :273-298.

9. Wang,X.Q., liang,X.G., \& Mao.,W.C. Analysis of key factors for the success of PPP [J]. International economic cooperation, 2007, (12) : 59-62.

10. Zhang,S.,liang,Y.H., \& Chen,J.J., et al. Research on key success factors of PPP project -- based on the 
analysis of typical cases at home and abroad [J]. Construction economics, 2018,(2):62-69.

11. Mladenovic,G.,Vajdic.N.,Wündsch.B.,et al. Use of key performance indicators for PPP transport projects to meet stakeholders'performance objectives[J]. Built Environment Project and Asset Management,2013,3(2):228-249.

12. Babatunde,S.O.,Opawole.A.,Akinsiku.O.E. Critical success factors in public-private partnership(PPP)on infrastructure delivery in Nigeria[J]. Journal of Facility Management,2012,10(3):212-225.

13. Li,B. Key factors for the success of public goods PPP construction model -- research environment based on urbanization process $[\mathrm{J}]$. Academic forum, 2016,(16):146-147.

14. Grimsey.D., Lewis.M.Public Private Partnerships:The Worldwide Revolution in Infrastructure Provision and Project Finance[M].Edward Elgar Publishing, 2007.

15. Li,B., Akintoye,A.,Edward,P.J.,et al. Critical success factors for PPP/PFI projects in the UK construction industry[J]. Construction Management and Economics,2005,23(5):459-471.

16. Osei-Kyei.R.,Chan,AP.C. Review of studies on the Critical Success Factors for Public-Private Partnership(PPP)projects from 1990 to 2013[J]. International Journal of Project Management,2015,33(6):1335-1346.

17. Zhao,J. Success factor analysis of PPP model of infrastructure project based on multi-agent perspective [J]. Financial science, 2016,(12):47-58.

18. Lu,X.Q.,Huang,Y.J., \& Wang,X. Research on risk intelligent evaluation of PPP project based on pa-rbf neural network [J]. Science and technology management research, 2017 (14) : 59-63.

19. Zhang,G.H., Niu,F.Y., \& Wang,J.B. et al. Risk prediction of low-rent housing PPP financing based on ppca - SVM [J]. Construction technology, 2016 (10) : 901-904.

20. Huang,K. Three-dimensional risk dynamic analysis model for full life cycle of PPP project [J]. Mathematical practice and understanding, 2019 (20) : 60-70. 